\title{
Fatal Aplastic Anemia Caused by Epstein-Barr Virus Infection after Autologous Bone Marrow Transplantation for Non-Hodgkin Malignant Lymphoma
}

\author{
Hirofumi Inoue, Kenji Shinohara, Jun Nomiyama and Eiichi Oeda
}

\begin{abstract}
We report a case of severe and fatal aplastic anemia during an episode of infectious mononucleosis caused by Epstein-Barr (EB) virus infection. The 13-year-old female patient had shown normal hematological findings and had previously undergone repeated chemotherapy and autologous bone marrow transplantation for refractory non-Hodgkin malignant lymphoma (NHL). She was probably in an immuno-suppressed condition prior to this episode of infection. The possible causal relationship of the $\mathrm{EB}$ virus infection in the pathogenesis of aplastic anemia was documented by the clinical course, demonstration of $\mathrm{EB}$ virus genome in the bone marrow cells, and an elevated plasma interferon (IFN)- $\gamma$ level.
\end{abstract}

(Internal Medicine 33: 303-307, 1994)

Key words: virus, pancytopenia

\section{Introduction}

The etiological agents of aplastic anemia are heterogeneous, and include chemicals, drugs, irradiation and viral infections (1). However, most cases are idiopathic (1). The viruses which can induce aplastic anemia include hepatitis virus, cytomegalovirus, Epstein-Barr (EB) virus, human immune deficiency virus, and parvovirus B19 $(2,3)$. However, most cases are diagnosed retrospectively based on indirect evidence such as the clinical manifestations, change in biochemistry, and rise in the levels of antibodies to the virus. Aplastic anemia caused by EB virus remains rare $(3,4)$. It occurs even in healthy individuals after the clinical course of infectious mononucleosis; the prognosis of patients with aplastic anemia caused by EB virus is not necessarily poor (4-6). However, fatal aplastic anemia has also been reported in previously healthy persons, immunodeficient patients, and in those with $x$-linked recessive lymphoproliferative disorders $(4,6-8)$. We recently treated a patient with fatal aplastic anemia after an episode of infectious mononucleosis caused by EB virus infection in a previously hematologically normal patient who had undergone repeated chemotherapy and autologous bone marrow transplantation for refractory non-Hodgkin malignant lymphoma.

\section{Case Report}

A 13-year-old female visited our hospital on May 25, 1993 because of fever and productive cough, and was admitted on June 1 . She had previously had large right neck lymph node swelling of approximately $6 \mathrm{~cm}$ in diameter, and small left neck, axillar and inguinal lymph node swelling on June 1988. The lymph node biopsy specimen revealed non-Hodgkin malignant lymphoma of the diffuse small cell type. The clinical stage was III by Ann Arbor classification (9). Even after entering complete remission by repeated courses of combination chemotherapy consisting of cyclophosphamide, mitoxantrone, etoposide and prednisolone, the tumor approximately $5 \mathrm{~cm}$ in diameter relapsed at left neck in 1990 and 1991. Judged as being refractory to standard dose chemotherapy, the autologous bone marrow cells were harvested on September 1991. The autologous bone marrow transplantation was performed on October 1992 at the third relapse following high-dose pre-conditioning chemotherapy with cytosine arabinoside, mitoxantrone and etoposide. The hematological recovery after transplantation was prompt. The clinical course after transplantation was favorable, and the patient was followed at the outpatient clinic until present admission. The chest $\mathrm{X}$-ray on this admission revealed an infiltrative shadow of the lung which was diagnosed as acute pneumonia. Antibiotics were administered, and the pulmonary

From the Division of Hematology, Department of Medicine, Yamaguchi Prefecture Central Hospital, Hofu

Received for publication October 15, 1993; Accepted for publication March 22, 1994

Reprint requests should be addressed to Dr. Kenji Shinohara, the Division of Hematology, Department of Medicine, Yamaguchi Prefecture Central Hospital, Hofu 747 
shadow improved gradually. Peripheral blood findings on admission were as follows: RBC, $451 \times 10^{4} / \mu \mathrm{l} ; \mathrm{Hb}, 11.5 \mathrm{~g} / \mathrm{dl}, \mathrm{Ht}$,

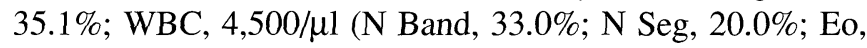
$1.0 \%$; Ba, $1.0 \%$; lymphocytes, $33.0 \%$; monocytes, $6.0 \%$; atypical lymphocytes, $6.0 \%$ ); platelet $11 \times 10^{4} / \mu$ l. Those for blood chemistry were; CRP $3.2 \mathrm{mg} / \mathrm{dl}$, GOT $257 \mathrm{u}$, GPT $134 \mathrm{u}, \mathrm{LDH}$ $974 \mathrm{u}$, serum immunoglobulin (Ig) G $590 \mathrm{mg} / \mathrm{dl}$, IgM $62 \mathrm{mg} / \mathrm{dl}$, IgA $35 \mathrm{mg} / \mathrm{dl}$. M protein was not observed. The liver enzymes increased; data on the 17th hospital day were as follows: GOT 941 u, GPT 506 u, LDH 1,307 u, $\gamma$-GTP 232 u, alk P 1,462 u. Values for these parameters gradually became normal thereaf- ter. The serological examination for EB virus infection revealed the following results: the antibodies for viral capsid antigen (VCA) IgG were $\times 640$ in 1987, ×2,560 in 1992 and $\times 640$ in 1933 , and anti-early antigen (EA) were $\times 160$ in $1987, \times 250$ in 1992 and $\times 160$ in 1933. Those for anti-VCA IgM and anti-EB virus nuclear antigen (EBNA), and heterophil antibodies were negative. The antibodies to hepatitis $\mathrm{A}, \mathrm{B}$, and $\mathrm{C}$ and that for cytomegalovirus were negative. The blood picture gradually deteriorated (Fig. 1), and marked pancytopenia appeared approximately 23 days after admission. The percentage of peripheral blood lymphocyte subsets were; CD4 50.7\% (normal
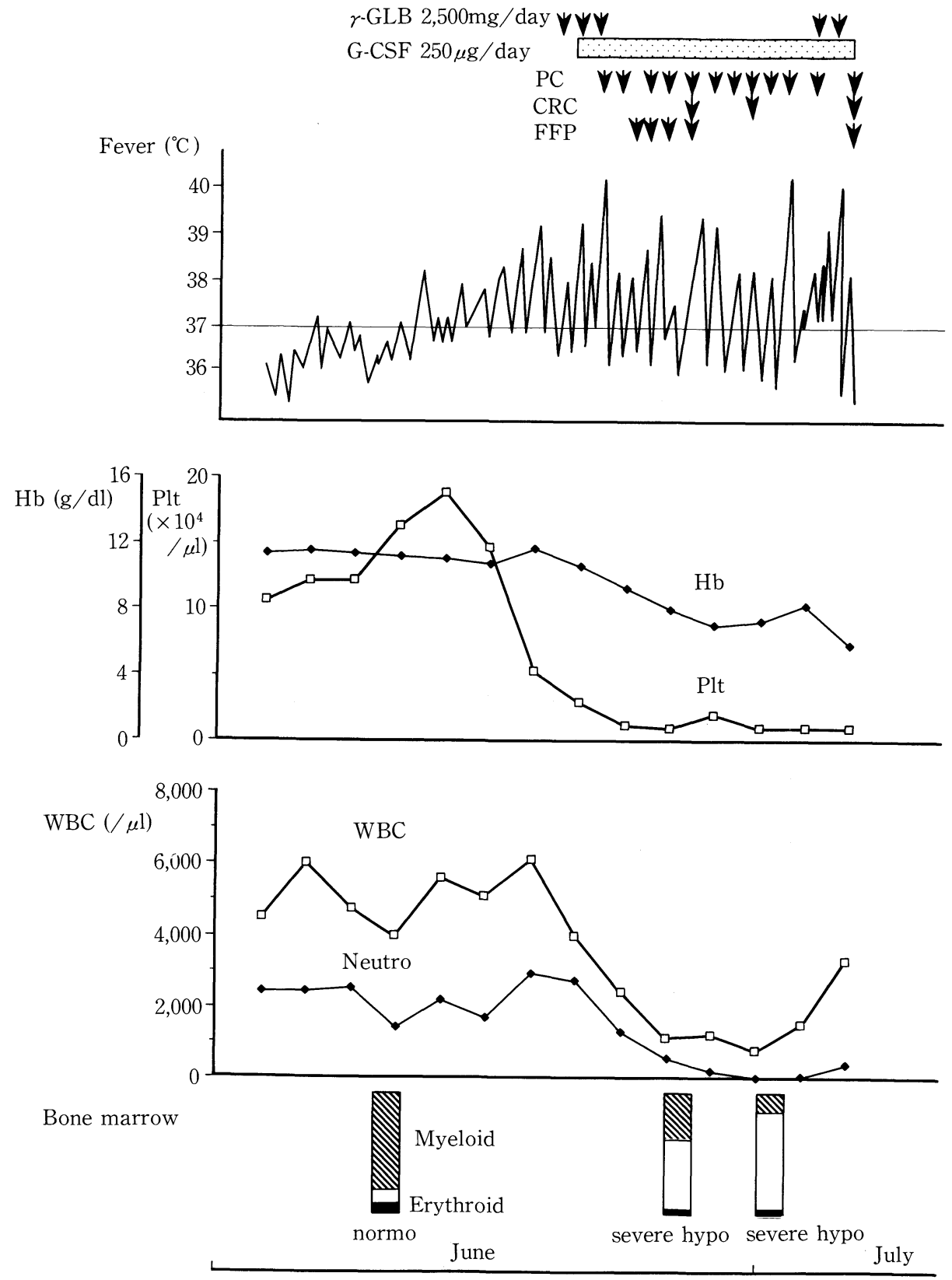

Fig. 1. The clinical course of the present patient. $\gamma$-GLB: gamma globulin, G-CSF: granulocyte-colonystimulating factor, PC: platelet concentrate, CRC: concentrated red cells, FFP: fresh frozen plasma. 
value, $25 \%-56 \%$ ), $\mathrm{CD} 848.1 \%$ (17\%-44\%), CD4/CD8 ratio 1.05 (0.6-2.9). Aspirated bone marrow smear examination revealed hypocellular marrow with a markedly decreased number of normal hematopoietic cells with erythroid, myeloid, and megakaryocytic features; infiltration of atypical lymphocytes was observed. Severe anemia, fever and hemorrhagic episodes developed, despite the administration of antibiotics, granulocytecolony-stimulating factor (G-CSF) and blood cell transfusion including red cells and platelets. Immunoglobulin $\mathrm{G}$ was administered at the dose of $2,500 \mathrm{mg} /$ day for 5 days. However, the hematological findings did not improve, and the patient died due to pneumonia on the 32 nd hospital day.

\section{Materials and Methods}

The Southern method of DNA analysis of EB virus DNA in the bone marrow blood was performed by a previously described method (10). DNA was extracted from the bone marrow cells by phenol-chloroform extraction and ethanol precipitation. The DNA was amplified by 30 cycles of polymerase chain reaction (PCR). The amplified DNA was electrophoresed and then hybridized with synthetic oligonucleotide probes coding for the Bam region of the EB virus genome, and was detected as a 125 base pair band. In situ hybridization for EB virus DNA in the bone marrow smears was performed using the ENZO Pathogene ${ }^{\circledR}$ DNA Probe Assay Kit (Enzo Diagnostics, Inc., Syosset, New York, USA).

The concentrations of following cytokines were measured in the peripheral blood plasma which was drawn on July 2, one day before death: erythropoietin (Epo), granulocyte colony-stimulating factor (G-CSF), granulocyte-macrophage-colony-stimulating factor (GM-CSF), interleukin (IL)-1 $\alpha$, IL-3, interferon (IFN)- $\gamma$ and tumor necrosis factor (TNF)- $\alpha$. The concentrations of G-CSF, GM-CSF, IL- $1 \alpha$, IL-3 and TNF- $\alpha$ were measured by the enzyme-linked immunosorbent assay (ELISA). G-CSF was measured by the previously reported method (11). GM-CSF was measured by human GM-CSF ELISA test kit (Genzyme Corporation, Boston, MA, USA). IL- $1 \alpha$ was measured by human IL-1 $\alpha$ assay kit (Otsuka Assay, Tokyo, Japan). IL-3 was measured by quantikine human IL-3 ELISA kit (R \& D Systems, Minneapolis, MN, USA). TNF- $\alpha$ was measured by TNF$\alpha$ assay kit (Otsuka Assay, Tokyo, Japan). Epo and IFN- $\gamma$ were measured by radioimmunoassay (RIA). Epo was measured by Epo RIA kit (Chugai, Tokyo, Japan). IFN- $\gamma$ was measured by Centocor gamma interferon RIA kit (Centocor Inc, Malvern, PA, USA).

\section{Results}

EB-virus DNA was detected in the patient's bone marrow blood using the Southern method of analysis (Fig. 2), however, it was not detected in the bone marrow cells in the aspirate smear by the in situ hybridization method. The concentrations of Epo, G-CSF and IFN- $\gamma$ in the peripheral blood plasma were elevated. Those of GM-CSF, IL- $1 \alpha$, IL-3 and TNF- $\alpha$ were under detectable limits (Table 1).

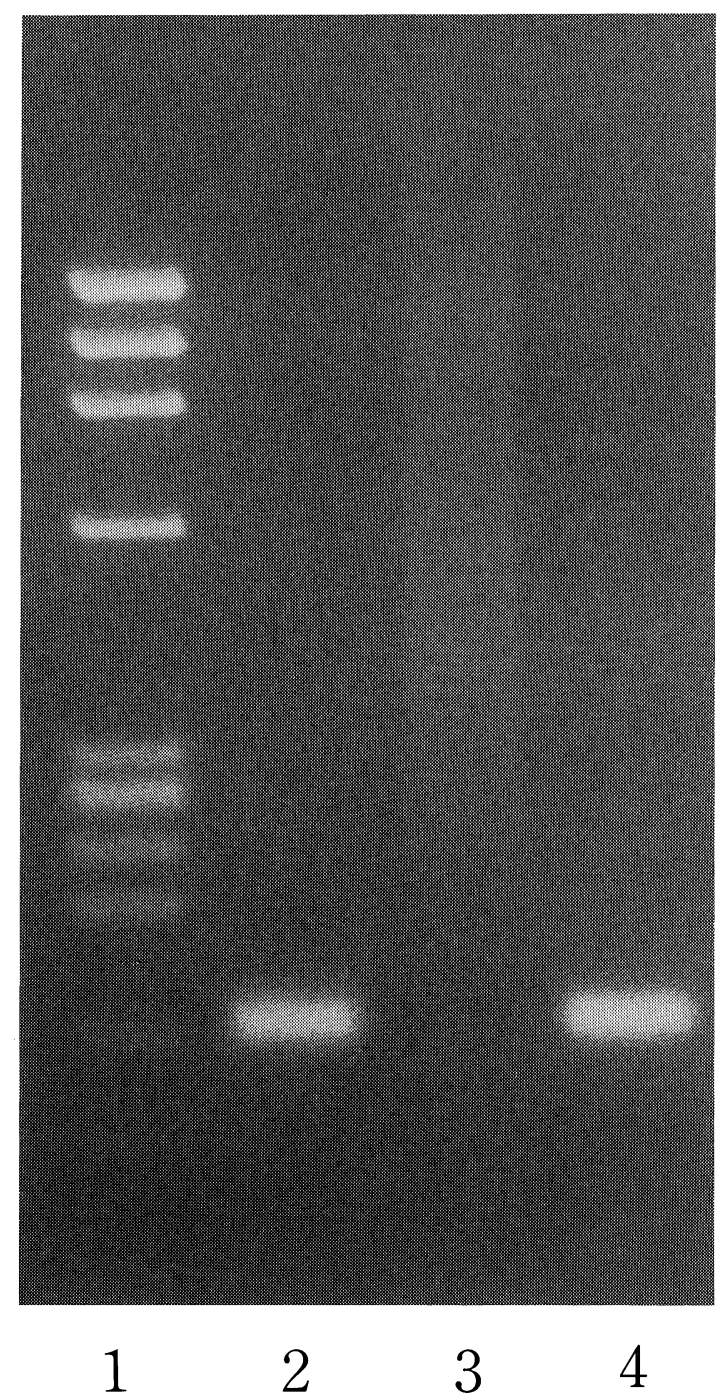

Fig. 2. Southern method of detection of EB virus DNA in bone marrow blood cells. 1) Size marker. 2) The positive control is P3HR-1 cell line DNA from Burkitt's lymphoma. 3) The negative control is human placental DNA. 4) The patient's bone marrow blood cells. The EB virus DNA is detected as a 125 base pair band.

Table 1. Levels of Plasma Cytokines on July 2.

\begin{tabular}{lcc}
\hline Cytokines (unit) & Patient's value & $\begin{array}{c}\text { Normal value } \\
\text { detection limit* }\end{array}$ \\
\hline Epo $(\mathrm{mu} / \mathrm{ml})$ & 630 & $12.5-34.5$ \\
G-CSF $(\mathrm{pg} / \mathrm{ml})$ & 12000 & $<39.1^{*}$ \\
GM-CSF $(\mathrm{pg} / \mathrm{ml})$ & $<2.00$ & $<5.00$ \\
IL-1 $\alpha(\mathrm{pg} / \mathrm{ml})$ & $<7.80$ & $<7.80^{*}$ \\
IL-3 $(\mathrm{pg} / \mathrm{ml})$ & $<31.3$ & $<31.3^{*}$ \\
IFN- $\gamma(\mathrm{u} / \mathrm{ml})$ & 0.72 & $<0.4$ \\
TNF- $\alpha(\mathrm{pg} / \mathrm{ml})$ & $<7.00$ & $<7.00^{*}$ \\
\hline
\end{tabular}

Epo: erythropoietin, G-CSF: granulocyte-colony-stimulating factor, GM-CSF: granulocyte-macrophage-colony-stimulating factor, IL- $1 \alpha$ : interleukin- $1 \alpha, \mathrm{IL}$ 3 : interleukin-3, IFN- $\gamma$ : interferon- $\gamma$, TNF- $\alpha$ : tumor necrosis factor- $\alpha$. 


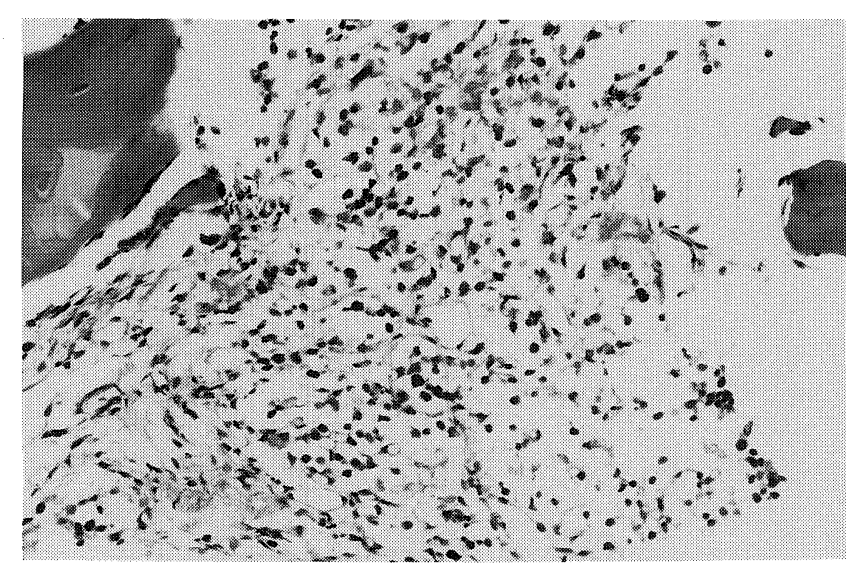

Fig. 3. The bone marrow necropsy specimen shows hypoplastic marrow, a decreased number of hematopoietic cells, and infiltration of lymphocytes (HE stain, $\times 200$ ).

Permission to conduct an autopsy was not obtained, but that for necropsy of the bone marrow and liver was performed. The bone marrow specimens demonstrated decreased bone marrow cell components, with infiltration of lymphocytes (Fig. 3). The liver specimen showed infiltration of lymphocytes in the Glisson's sheath area (Fig. 4).

\section{Discussion}

Infectious mononucleosis is, with rare exception, a selflimiting disease (6). This patient first suffered from infectious mononucleosis, when elevated liver enzymes, fever and pneumonia without peripheral blood cytopenia were observed, and aplastic anemia subsequently developed. The cause of the EB virus infection in this patient may have been chronic active infection, since an increase in anti-VCA IgG antibody and antiEA antibody was observed (6). This patient had previously received repeated chemotherapy and autologous bone marrow transplantation for the relapsed refractory malignant lymphoma, and had a low serum level of IgG at admission, suggesting that she was in an immuno-suppressed condition.

The reported hematological complications of EB virus infection are hemolytic anemia, granulocytopenia, thrombocytopenia, aplastic anemia, and hemophagocytic syndrome (6). The frequency of EB virus-caused aplastic anemia is low (3, 4); EB virus DNA and protein were detected in only 1 of 40 patients with aplastic anemia studied retrospectively (4). The effect of viral infection on the suppressed hematopoiesis in patients with aplastic anemia is not fully understood $(3,4)$. While the B cells are the recognized target of EB virus infection, other cells may also harbor this virus (e.g., nasopharyngeal epithelial cells). Some hematopoietic cells may also be infected by $\mathrm{EB}$ virus $(3,4,12)$. EB virus nuclear antigen (EBNA) is detected by immunofluorescence and $\mathrm{EB}$ virus DNA is detected by in situ hybridization in B cell-depleted bone marrow cells (3, 4). EB virus DNA is also observed in the monocyte-macrophage precursors (12). The typical strains of EB virus are not inhibi-

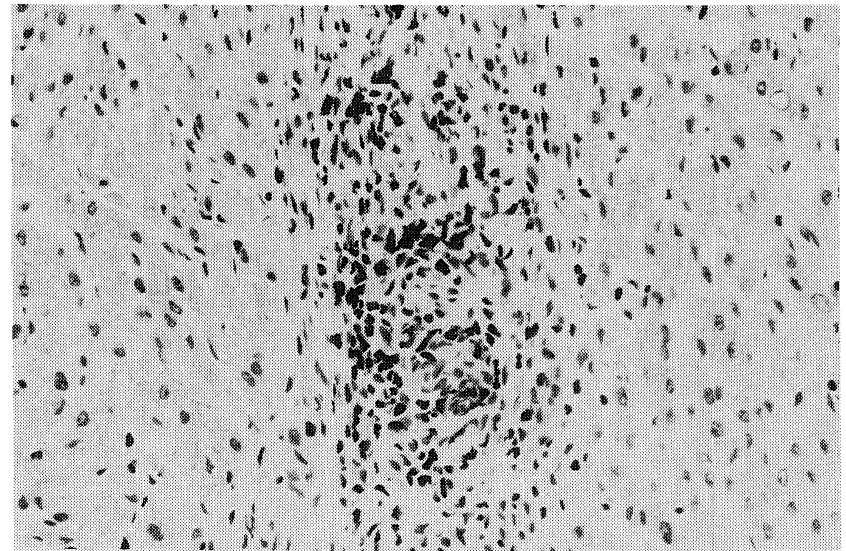

Fig. 4. The liver necropsy specimen shows infiltration of lymphocytes in the Glisson's sheath area (HE stain, $\times 200)$.

tory of normal hematopoiesis in vitro, but EB virus-exposed cells may be more susceptible to T cell-mediated cytotoxicity (3). However, the EB virus isolated from patients with aplastic anemia possesses molecular and biological properties associated with a cytolytic, non-transforming, strain in contrast to the typical, transforming, EB virus commonly obtained from infected persons (4). The EB virus infects B-lymphocytes, as well as T-cells, and increases activated T-cells and cytotoxic T-cells, decreases helper T-cells, and increases production of IFN- $\gamma(3$, 4). These cellular and humoral effects on hematopoietic stem cells are considered to be involved in hematopoiesis suppression in aplastic anemia $(13,14)$. Indeed, the concentration of IFN- $\gamma$ in the plasma of our patient was elevated along with the erytropoietin level which reflects the severity of anemia. The elevated level of G-CSF reflects the effect of G-CSF administration as well as endogenous production. Cytomegalovirus infection contributes to bone marrow suppression in some cases of allogeneic and autologous bone marrow transplantation (15). Hematopoietic progenitor cells or accessory cells such as monocytes, $\mathrm{T}$ lymphocytes, fibroblasts and endothelial cells which are considered to provide growth factors may be the target of infection either by direct lysis or by interfering with their function (15).

It is often difficult to confirm that viral infection is the cause of aplastic anemia, since aplastic anemia is usually the end result of the disturbed hematopoiesis, by which time either the virus is not detected, or the virus infection is slight (4). In our patient, the process of development of aplastic anemia caused by EB virus infection was observed.

The viral DNA in the bone marrow blood could be demonstrated by the Southern method, in which DNA was amplified with PCR. The demonstration of the EB virus genome in the bone marrow blood might be a significant finding. However, the precise meaning in the pathogenesis of aplastic anemia remains unknown, since we could not localize the infected target cells in the bone marrow cells in the aspirate smear by the in situ hybridization method. This may have been due to the scarcity 
of bone marrow cells in the hypocellular marrow and the low sensitivity of the in situ hybridization method. Indeed, positivity for viral DNA has been observed in only a small percentage of bone marrow cells (4). EB virus has been observed to be associated with lymphoproliferative and neoplastic diseases such as nasopharyngeal carcinoma, Burkitt's lymphoma, and non-Hodgkin B-cell and T-cell lymphoma. The infiltration of lymphocytes in the bone marrow and liver in the present patient would indicate the reactive proliferation of activated lymphocytes rather than the infiltration of malignant lymphoma cells.

With regard to treatment, antiviral agents and immunoglobulins have been reported to be effective (6). Clinical trials have not shown acyclovir therapy to be effective in patients with acute infectious mononucleosis or with serious EB virus infection associated with $\mathrm{X}$-linked lymphoproliferative diseases $(6$, $16,17)$. However, a reduced level of EB virus expression in bone marrow cells has been observed in some patients (4). We administered immunoglobulins, without effect, but did not administer acyclovir, since the clinical course was too rapid. Immuno-suppressive agents, such as anti-thymocyte globulin and cyclosporin A, may be effective for immune-mediated aplastic anemia (18). Corticosteroids have been reported to be useful in EB virus-induced aplastic anemia (5), and hematological recovery has been observed in some patients. However, we did not administer these agents in the present patient because of the severe infection and possible immunosuppressed condition.

\section{References}

1) Shahidi NT. Acquired aplastic anemia: classification and etiologic considerations. in: Aplastic Anemia and Other Bone Marrow Failure Syndromes, Shahidi NT, Ed. Springer-Verlag, New York, 1990, p.25.

2) Young N, Mortimer P. Virus and bone marrow failure. Blood 63: 729, 1984.

3) Kurzman G, Young N. Viruses and bone marrow failure. Bailliere's
Clinical Hematology 2: 51, 1989.

4) Baranski B, Armstrong G, Truman JT, Quinnan GV, Straus SE, Young NS. Epstein-Barr virus in the bone marrow of patients with aplastic anemia. Ann Intern Med 109: 695, 1988.

5) Grishaber JE, McClain KL, Mahoney DH, Fernbach DJ. Successful outcome of severe aplastic anemia following Epstein-Barr virus infection. Am J Hematol 28: 273, 1988.

6) Straus SE, Cohen JI, Tosato G, Meier J. Epstein-Barr virus infections: Biology, pathogenesis and management. Ann Intern Med 118: 45, 1993.

7) Purtilo DT, Deflorio D, Hutt LM, et al. Variable phenotypic expression of an X-linked recessive lymphoproliferative syndrome. N Engl J Med 297: 1077, 1977.

8) Straus SE. Acute progressive Epstein-Barr virus infections. Annu Rev Med 43: 437, 1992.

9) Symposium: Staging in Hodgkin's Disease. Cancer Res 31: 1712, 1971.

10) Saito I, Servenius B, Compton T, Fox RI. Detection of Epstein-Barr virus DNA by polymerase chain reaction in blood and tissue biopsies from patients with Sjögren's syndrome. J Exp Med 169: 2191, 1989.

11) Motojima H, Kobayashi T, Shimane M, Kamachi S, Fukushima M. Quantitative enzyme immunoassay for human granulocyte colony stimulating factor (G-CSF). J Immunol Methods 118: 187, 1989.

12) Revoltella RP, Vigneti E, Fruscalzo A, et al. Epstein-Barr virus DNA sequences in precursor of monocyte-macrophage cell lines established from the bone marrow of children with maturation defects of haematopoiesis. J Gen Virol 70: 1203, 1989.

13) Zoumbos NC, Gascon P, Djeu JY, Young NS. Interferon is a mediator of hematopoietic suppression in aplastic anemia in vitro and possibly in vivo. Proc Natl Acad Sci 82: 188, 1985.

14) Zoumbos NC, Gascon P, Djeu JY, Trost SR, Young NS. Circulating activated suppressor $\mathrm{T}$ lymphocytes in aplastic anemia. $\mathrm{N}$ Engl J Med 312: $257,1985$.

15) Torok-Storb B, Fries B, Myerson D. Cytomegalovirus mediated cytopenias. in: The Negative Regulation of Hematopoiesis, Guigon M, Lemoine FM, Dainiak N, Schechter A, Najman A, Eds. Libbey Eurotext Ltd, Paris, 1993, p.383.

16) Andersson J, Britton S, Ernberg I, et al. Effect of acyclovir on infectious mononucleosis: a double-blind, placebo-controlled study. J Infect Dis 153: 283, 1986.

17) Sullivan JL, Byron KS, Brewster FE, Sakamoto K, Shaw JE, Pagano JS. Treatment of life-threatening Epstein-Barr virus infections with acyclovir. Am J Med 73: 262, 1982.

18) Gluckman E, Devergie A, Poros A, Degoulet P. Results of immunosuppression in 170 cases of severe aplastic anemia. Br J Haematol 51: $541,1982$. 